\title{
THE DETERMINANT OF FINANCIAL INFORMATION DISCLOSURE ON INDONESIAN LGs WEBSITE
}

\author{
Kurniawan Cahyo Utomo \\ Y Anni Aryani \\ Fakultas Ekonomi dan Bisnis - Universitas Sebelas Maret \\ Email: kurniawancuklaten@gmail.com,yanniar@yahoo.com
}

\author{
ARTICLE INFORMATION \\ Article history: \\ Received July 27, 2015 \\ Revised November 30, 2015 \\ Accepted February 22, 2016

\section{JEL Classifications} \\ M40

\section{Key Words:} \\ Disclosure, \\ Transparency, \\ Local government (LGs), \\ Website \\ DOI: \\ 10.21532/apfj.001.16.01.01.07
}

\begin{abstract}
This research aims to find out the effect of size, leverage, wealth, audit opinion, liquidity, and press visibility of Local Governments (LGs) on the financial information disclosure through Indonesian LGs website. Center for Regional Information Study (Pattiro) states that only 28\% of LGS disclose their financial information through website, and this proves lack of public transparency. This research method is using multiple linear regression. The population is 456 Local Governments (LGs) in Indonesia, with the research sample as many as 187 LGs conducted using purposive sampling method. The type of research data is secondary data. Empirical results show that size and wealth have positive effect on the financial information disclosure through website. Press visibility has negative effect on the financial information disclosure through website. While leverage, audit opinion, and liquidity do not have effect on the financial information disclosure through website. The implication of this research is that The Ministry of Home Affairs could develop a system of reward and punishment to motivate the LGs to improve their level of financial information disclosure through the website.
\end{abstract}

\section{INTRODUCTION}

According to Law No. 14 of 2008, everyone has rights to obtain information. Public Agencies, therefore, have an obligation to provide and serve the requested information quickly, timely, cheaply and simply. By disclosing information to public, Local Governments (LGs), as part of Public Agencies, will have motivation to account for the mandate of the people and be more oriented on public service so as to prevent the emergence of corruption, collusion and nepotism. 
In realizing public information transparency, the disclosure of public information has become an important tool of public control over the government performance. The disclosure via website will enable the public to access information easily, to increase transparency and to minimize costs in administering the state. Moreover, every public information must be open and accessible to all public information users (Law No. 14 of 2008). In addition to providing the impression of democratic value, online services via website can also improve the performance of users due to their satisfaction in using e-government (Huang and Benyoucef, 2014).

Information related to financial statements shall be provided and published periodically to the public (Law No. 14 of 2008). At present, unfortunately, the disclosure of financial information via internet is still conducted voluntarily. Each Local Government, in accordance with the Instruction of the Ministry of Home Affairs Number 188.52 / 1797 / SJ of 2012 , is instructed to publish documents related to its regional budget in the content menu of Regional Budget Management Transparency page (website). But in practice, not all LGs execute this instruction which is caused by the LGs' low level of transparenc. Based on the findings of Center for Regional Information Study (Pattiro), only 28\% of Indonesian LGs disclose their financial information via website (Pattiro 2014).

The gap in this study is that the financial information disclosure via LGs website is still done voluntarily, not mandatorily. The non- mandatory disclosure of information always becomes the reason for the LGs not to disclose their financial information via their official website. On the other hand, the public always demands for financial information transparency, which is basically as the human rights and becomes an important feature of democratic country. The issue of transparency in financial information disclosure may arise because of the existence of digital gap, where, in general, there is a difference between those who have and those who do not have access to the internet (Reddick and Turner 2012) and it is generally related to the population (Sol 2013; Reddick and Turner, 2012; Alvarez, Dominguez, and Sanchez, 2010). Several previous studies (Laswad, Fisher, and Oyelere 2005; Garcia and Garcia, 2010; Medina 2012; Trisnawati and Ahmad, 2014; Sinaga and Prabowo 2011; Rahman, Sutaryo, and Budiatmanto 2013; Afryansyah and Haryanto, 2013; Styles and Tennyson 2007) examined factors relating to the LGs financial information disclosure via internet and the financial information disclosure in private sector (Aly, Simon, and Hussainey 2010; Simanjuntak and Widiastuti; 2004). Such factors include size, leverage, wealth, audit opinion, liquidity, and press visibility, but the results are still inconsistent.

The purpose of this study is to find out the effect of LGs' size, leverage, wealth, audit opinion, liquidity, and press visibility on the financial information disclosure via Indonesian LGs website. Good governance can be realized by utilizing technology and information that focuse on transparency, 
openness, citizen participation, effectiveness, efficiency, accountability, and others (Lupu and Lazar, 2015). The transparency of government which is expressed via website can prevent the occurrence of corruption because public can perform monitoring. Based on the findings of Center for Regional Information Study (Pattiro), does it have any influence with the different characteristics of LGs in Indonesia?

\section{THEORITICAL FRAMEWORK AND HYPHOTESIS DEVELOPMENT}

\section{Agency Theory}

In agency relationship, it is stated that a principal, as the owner of authority, gives his authority and responsibility to an agent to make the best decisions in accordance with the interests of the principal (Jensen and Meckling, 1976; Medina, 2012; Trisnawati and Achmad, 2014). The agent, therefore, morally has the burden of responsibility to maximize the principal's profit. And the agent, on his efforts, will receive compensation as contained in the contract. The delegation of authority gives rise to agency problem because of the differences of interest or lack of trust of both sides. Efforts to minimize the agency problem can lead to agency costs. Agency costs can be classified into three types, namely monitoring cost, bonding cost, and residual loss (Jensen and Meckling, 1976).

In the context of government, principal refers to the people, and agent refers to the government that is given mandate to improve the people welfare. Information disclosure on internet can reduce information asymmetry
(Alvarez et al, 2010) and lower agency costs (Oyelere, Laswad, and Fisher, 2003; Hassan, Giorgioni, Romilly, and Power, 2009). The government will seek to disclose information voluntarily via internet to convince the people that the government has actually acted optimally in accordance with the people's whishes to guarantee the people through bonding cost. In addition, the government is also aware that people are trying to control their behavior through monitoring and incentive compensation through monitoring cost.

\section{Signalling Theory}

Signalling theory is a theory that explains where the government as the party that receives a mandate from the people is trying to be able to show positive signal to the people (Trisnawati and Achmad, 2014; Martani, Fitriasari, Annisa, 2014). The government drive in providing information is caused by the existence of information asymmetry between government and outside parties. One of the efforts to reduce the information asymmetry is by providing signals to outside parties related to positive and trustworthy information. The signals can be in the form of achievements that have been accomplished or the disclosure of more detailed and complete financial information via website. Good signals can both minimize the uncertainty of LGs prospect and increase the confidence of outside parties on the LGs performance.

\section{Transparency and Information Disclosure through Internet}

The concept of government transparency 
is the overall levels where citizens, media and financial markets can observe strategies, activities and results made by the government (Alt and Lassen 2006). Piotrowski and Bertelli (2010) underlined that the government transparency is the levels of access to the availability of government information. The transparency can provide an opportunity to the public to know the public policy that has been and will be made by the government, increase the effectiveness of public policy, and reduce the uncertainty of government policy. This is because transparency can become necessary tools to monitor and evaluate the performance of legislators and bureaucrats (Sol, 2013). To decrease the level of corruption, transparency has a role in providing better context for the economic growth, efficiency, and development as a means of improving governance (Meón and Weill, 2005). In addition, transparency is a form of the implementation of the Law on Public Information Openness in which the state administration should be implemented transparently, effectively, efficiently, and accountably.

Internet improves the interaction between citizens and government, and this is what distinguishes from traditional public administration (Chadwick, 2003). The internet usage can also improve internal business processes, improve service quality, increase citizen participation, and enable to disseminate government information more easily and cheaply (Moon, Lee, and Roh, 2014). Website helps the users find the financial information via web pages, links on homepage, and search engine (Styles and Tennyson, 2007).
Financial information is not the ultimate goal of accounting in public sector, but its function is as the basis for decisionmaking (Mardiasmo, 2005). A way that is considered convenient and cost-effective for the government in disseminating information today is through internet (Styles and Tennyson, 2007). According to Governance Finance Officers Association (GFOA), in the Styles and Tennyson (2007), the benefits of the disclosure via internet are (a) increasing the concern of the document existence, (b) increasing the use by stakeholders, (c) as an analytical tool that is easy to apply, (d) preventing the excessive disclosure and saving publication cost.

Special provision that requires the LGs financial information to be published via internet has not been set. If a local government performs financial reporting via internet, it is only done voluntarily (Sinaga and Prabowo, 2011). The disclosure of financial information via internet is a voluntary disclosure (Trisnawati and Achmad, 2014; Sinaga and Prabowo, 2011). The voluntary disclosure is not a compulsory matter so that the disclosure is just an option / alternative choice for the LGs that want to disclose it (Medina, 2012) and as a way of improving the LGs credibility so as to make investors understand the LGs business strategies.

\section{The Effect of Size on Information Disclosure}

The greater the level of services and functions to be provided by large LGs will encourage the LGs to produce larger and more sophisticated website (Styles and Tennyson, 
2007). Large LGs have no problems in reporting their financial information on internet because their large total assets can afford to fund the financial reporting via internet (Rahman et al, 2013). Through website, the LGs can provide financial information quickly. Besides, the LGs can also reduce agency cost related to the dissemination of informasi. Researches by Styles and Tennyson (2007), Garcia and Garcia (2010), Medina (2012), Trisnawati and Achmad (2014) showed that size has an effect on financial information disclosure via website. However, different results are shown by Laswad et al (2005), Sinaga and Prabowo (2011), Rahman et al (2013), and Afryansyah and Haryanto (2013). Based on the description above, the first hypothesis proposed is:

\section{$\mathrm{H}_{1}$ : Size has positive effect on financial information disclosure through LGs website}

The Effect of Leverage on Information Disclosure

Debt derived from creditor will make the creditor always try to monitor the LGs performance. The higher the leverage, the larger the monitoring conducted by the creditor. So, besides having a high cost of debt, the LGs also bear the cost in meeting the creditor monitoring. In line with the agency theory, to reduce the cost, the government tries to make voluntary disclosure through website. Researches by Laswad et al (2005), Rahman et al (2013), Trisnawati and Achmad (2014) showed that leverage has an effect on financial information disclosure voluntarily made by the LGs via internet. However, the researches by Sinaga and Prabowo (2011) and Medina (2012) showed that leverage has no effect on financial information disclosure made by the government through its official website. Based on the description above, the second hypothesis proposed is:

\section{$\mathrm{H}_{2}$ : Leverage has positive effect on financial information disclosure through LGs website}

\section{The Effect of Wealth on Information}

\section{Disclosure}

The LGs with a great wealth will have good performance and are deemed to have run the mandate of the people well. It is consistent with the concept of signaling theory that the LGs owning great wealth will tend to make more disclosure than those owning poor performance because they want to show their positive side to the people. Instead, the LGs with smaller wealth will tend to restrict the access their financial information users (Laswad et al, 2005). Researches by Laswad et al (2005), Rahman et al (2013), Trisnawati and Achmad (2014) showed that the LGs wealth has an effect on LGs financial information disclosure via internet. However, the researches by Sinaga and Prabowo (2011); Afryansyah and Haryanto (2013) showed that LGs wealth has no effect on LGs financial information disclosure via internet. Based on the description above, the third hypothesis proposed is:

\section{$\mathrm{H}_{3}$ : Wealth has positive effect on financial information disclosure through LGs website}




\section{The Effect of Audit Opinion on Information}

\section{Disclosure}

LGs consider unqualified opinion as a form of appreciation for reliable and accountable financial management so that the LGS tend to perform financial information disclosure via website to provide a signal on their financial management. While the LGs with poor audit opinion can lead to the public perception that the LGs financial management is not well done so that the LGs tend to cover the financial information by not presenting it via website. The research by Styles and Tennyson (2007) showed that LGs audit opinion also has an effect on LGs financial information disclosure via internet. However, The research by Trisnawati and Achmad (2014) could not prove that the audit opinion has an effect on the publication of LGs financial information disclosure via internet. Based on the above description, the fourth hypothesis proposed is:

\section{$\mathrm{H}_{4}$ : Audit Opinion has positive effect on financial information disclosure through LGs website}

\section{The Effect of Liquidity on Information Disclosure}

LGs high liquidity can influence the investment decision made by investors. Investors assume that the LGs with high liquidity will be free of bankruptcy. The LGs with high liquidity will try to show a signal of their financial information by disclosing such information on the website, in which it is consistent with the concept of signaling theory. The research by Simanjuntak and Widiastuti
(2004) showed that the characteristic of companies with high liquidity ratios is related to the level of voluntary disclosure of the manufacturing companies listed on Indonesia Stock Exchange. Different result is shown by Aly et al. (2010) where liquidity does not prove to have an effect on the company's accounting information disclosure via internet in Egypt. Based on the description above, the fifth hypothesis proposed is:

\section{$\mathrm{H}_{5}$ : Liquidity has positive effect on the disclosure of financial information through LGs website}

\section{The Effect of Press Visibility on Information \\ Disclosure}

Zimmerman (1977) in Garcia and Garcia (2010) stated that media has an important role as a moderator on the agency relationship between voters and LGs. But media is usually more interested in presenting the news related to negative things. This makes the LGs so depressed that they tend to be more encouraged to disclose their financial information via the website, in which it is in accordance with the concept of signaling theory. LGs hope that this disclosure may present an overview to the public that the actual conditions are not the same as stated by the media. Research by Laswad, et al (2005) showed that the LGs press visibility also has an effect on LGs financial information disclosure via internet. LGs with high press visibility would tend to disclose their financial information through the internet. While different results are shown by Garcia and Garcia (2010) and Afryansyah and Haryanto (2013), that press visibility does not prove to 
have an effect on LGs accounting information disclosure via internet. Based on the description above, the sixth hypothesis proposed is:

\section{$\mathrm{H}_{6}$ : Press visibility has positive effect on financial information disclosure through LGs website}

All the research hypothesis above can be described within the framework in Figure 1. owned by local governments in Indonesia, the Report of Financial Investigation Bureau of Indonesia (LHP BPK RI) of 2013 obtained from The Financial Investigation Bureau of Indonesia (BPK RI), population data from the website of the Ministry of Home Affairs, and the alexa traffic ranks obtained from www. alexa.com.

Figure 1

Framework

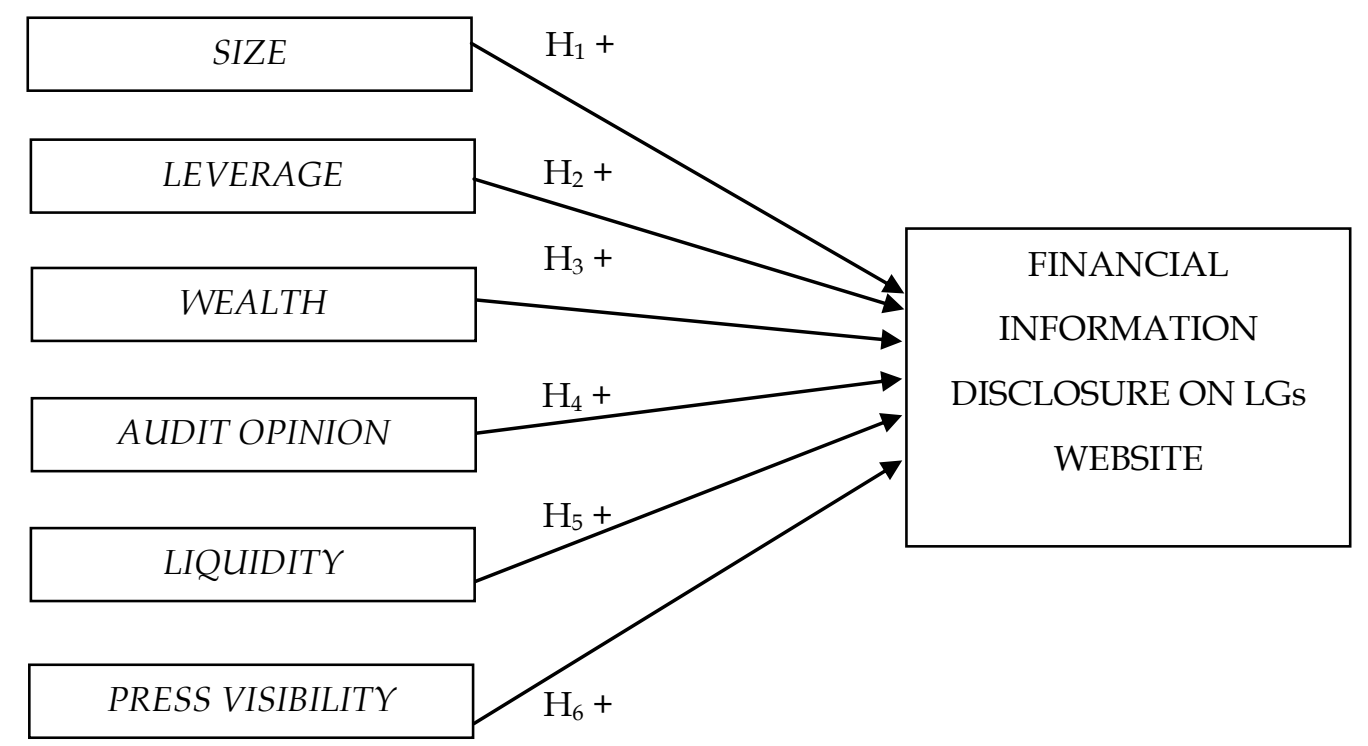

\section{RESEARCH METHOD}

\section{Population, Sample, and Sampling Technique}

The population used in this study is local governments throughout Indonesia based on the Report of Financial Investigation Bureau of Indonesia (LHP BPK RI) of 2013 consisting of 456 Local Governments (LGs). The sampling design in this study is using nonprobability sampling in the form of purposive sampling. Type of data in this study is using secondary data. The data used in this research are the websites

\section{Operational Definition and Variable} Measurement

Disclosure means providing data that can give benefits to those in need (Ghozali and Chariri 2007). The measurement of the variable of financial information disclosure refers to the research by Mudyastuti (2014) with some modifications tailored to the Instruction of Ministry of Home Affairs No. 188.52 / 1797 / SJ 2012. The data of LGs financial information are obtained by accessing to the website of each local government (accessed from May 16 to June 20,2015). The total score generated by the 
LGs based on the information availability has a maximum score of 12 . The scores produced by each local government are further divided by the maximum score, then multiplied by $100 \%$ to get the ratio of LGs financial information disclosure index.

Size means the (large or small) size of a local government (Sinaga and Prabowo, 2011). Size in this research is measured by natural logarithm (Ln) of the total assets of a local government, which refers to the research conducted by Trisnawati and Achmad (2014).

Leverage is the ability of LGs in securing the funds borrowed by using the amount of assets owned by the LGs (Rahman et al, 2013). Leverage is measured by total debt compared to total assets, which refers to the research by Alyet al. (2010).

LGs Wealth is defined as the level of prosperity of a region (Trisnawati and Achmad, 2014). Wealth is measured by the LGs total revenue (PAD) compared to the $\mathrm{LGs}$ total population, which refers to the research by Trisnawati and Achmad (2014). The number of LGs population used is the total population in 2013 obtained from the website of the Ministry of Home affairs (accessed from 15 to 16 May 2015).

The definition of opinion according to the Law No. 15 of 2004 is the auditors' professional statement related to the fairness of the financial information presented in the financial statement. The measurement of audit opinion refers to the research conducted by Fontanella and Rossieta (2014) with the code "1" for disclaimer opinion

(TMP), code "2" for adverse opinion (TW), code " 3 " for qualified opinion (WDP), code " 4 " for unqualified opinion with explanatory paragraph (WTP-DPP), and code "5" for unqualified opinion (WTP).

LGs liquidity is the ability of LGs to meet their short-term debt obligations without having to liquidate the assets or close the LGs (Turley et al, 2015). Liquidity is measured by current assets compared to current liabilities of the LGs, which refers to the research by Aly et al, (2010).

Press visibility is a pressure faced by the LGs caused by the demand of information from the media or even as a defensive mechanism of the elected politicians (Gand1'a and Archidona, 2008). Press visibility is measured by the ranking of the number of visitors to the LGs website using alexa traffic rank based on www.alexa.com (accessed from 16 to 18 May 2015). This measurement refers to the research conducted by Novianty (2012).

\section{Analysis Method}

This study uses multiple linear regression model to determine the effect of several independent variables on a dependent variable (Sekaran and Bougie, 2013). The research model used to test the hypothesis is as follows:

Y

$$
\begin{aligned}
& =\boldsymbol{\beta}_{0}+\boldsymbol{\beta}_{1} X_{1}+\boldsymbol{\beta}_{2} X_{2}+\boldsymbol{\beta}_{3} X_{3}+\boldsymbol{\beta}_{4} \\
& X_{4}+\boldsymbol{\beta}_{5} X_{5}+\boldsymbol{\beta}_{6} X_{6}+\boldsymbol{e}
\end{aligned}
$$

$$
\begin{array}{ll}
\text { Description: } & \\
\mathrm{Y} & =\begin{array}{l}
\text { Index of financial information } \\
\text { disclosure on LGs website }
\end{array} \\
& =\text { LGs size } \\
\mathrm{X}_{1} & =\text { LGs debt payment ratio } \\
\mathrm{X}_{2} &
\end{array}
$$




$$
\begin{aligned}
& \mathrm{X}_{3} \quad=\text { LGs wealth } \\
& \mathrm{X}_{4} \quad=\text { Audit opinion } \\
& \mathrm{X}_{5} \quad=\text { LGs liquidity Likuditas } \\
& \mathrm{X}_{6} \quad=\text { Press visibility } \\
& \beta_{0}, \beta_{1}, \ldots, \beta_{6}=\text { Regression coefficient } \\
& e=\text { Errors }
\end{aligned}
$$

The hypothesis testing is using determination coefficient (adjusted $\mathrm{R}^{2}$ ), simultaneous significance test ( $\mathrm{F}$ test), and partial significance test ( $\mathrm{t}$ test).

\section{DATA ANALYSIS AND DISCUSION}

Based on the purposive sampling, the number of samples of this research is 187 local governments (LGs). The samples criteria can be seen in Table 1, while the results of the descriptive statistic test can be seen in Table 2 .

Table 1

Sample Data

\begin{tabular}{lc}
\hline \multicolumn{1}{c}{ Description } & Total \\
\hline LGs Financial Statements (LKPD) of 2013 that have been audited by & 456 \\
Financial Investigation Bureau of Indonesia (BPK RI) & \\
LGs Financial Statements (LKPD) are not available & $(1)$ \\
LGs do not provide financial information & $(107)$ \\
LGs total population data are not available & $(29)$ \\
LGs do not have website & $(14)$ \\
LGs Website cannot be opened/offline/malfunction & $(19)$ \\
LGs do not have debts & $(15)$ \\
LGs are out of range based on www.alexa.com & $(7)$ \\
LGs as outliers & $(77)$ \\
Samples Data obtained & 187 \\
\hline
\end{tabular}

Table 2

Descriptive Statistic

\begin{tabular}{llrrrr}
\hline & $\mathrm{N}$ & \multicolumn{1}{c}{ Minimum } & \multicolumn{1}{c}{ Maximum } & \multicolumn{1}{c}{ Mean } & \multicolumn{1}{c}{ Std Deviation } \\
\hline SIZE & 187 & 27.13 & 29.98 & 28.3887 & .50423 \\
\hline LEVERAGE & 187 & .00 & .06 & .0083 & .01027 \\
\hline WEALTH & 187 & 34892.01 & 1044186.65 & 226087.8918 & 189888.53987 \\
\hline $\begin{array}{l}\text { AUDIT } \\
\text { OPINION }\end{array}$ & 187 & 1.00 & 5.00 & 3.5668 & .96697 \\
\hline LIQUIDITY & 187 & & & & \\
\hline PRESS & 187 & 125909.00 & 18315941.00 & 2860498.155 & 3103525.26910 \\
VISIBILITY & & & & & .4207 \\
\hline ON WEB & 187 & .08 & 1.00 & & .31730 \\
Valid N & 187 & & & & \\
$($ listwise) & & & & & \\
\hline
\end{tabular}


The variable of size has minimum value of 27.13 with total asset value of IDR 604,144,963,828.06 (Bolaang Mongondow Timur Regency) and maximum value of 29.98 with total asset value of IDR 10,480,678,263,254 (Samarinda City). The mean value is 28.3887 with total asset value of IDR 2,133,358,010,602. This indicates that Samarinda City has total asset value of nearly 5 times as many as the average total assets of LGs in Indonesia

The variable of leverage has minimum value of 0.00 (Klaten Regency) and maximum value of 0.06 (Ogan Ilir Regency) with the mean value of 0.0083 . This indicates that Ogan Ilir has a ratio of total debt compared to total asset which is very big when compared to the average LGs in Indonesia or equal to sevenfold.

The variable of wealth has minimum value of $34,892.01$ and maximum value of 1,044,186.65 (Denpasar City) with the mean value of 226,087.8918 and standard deviation value of $189,888.53987$. This indicates that the majority of LGs in Indonesia have the levels of prosperity between 36,199 and 415,976 or far below Denpasar City.

The variable of audit opinion which is measured using ordinal scale has minimum value of 1.00 and maximum value of 5.00, with the mean value of 3.5668 . This indicates that most LGs in Indonesia receive audit opinion in the form of qualified opinion (WDP) and unqualified opinion with explanatory paragraph (WTP-DPP).
The variable of liquidity has minimum value of 0.18 and maximum of $12,038.76$ (Klaten Regency), with the mean value of 200.4998 . This indicates that the Government of Klaten has a ratio of current assets compared to current liabilities far in excess of the average of the majority of LGs in Indonesia or equivalent to sixty-fold.

The variable of press visibility has minimum value of $125,909.00$ and maximum value of $18,315,941.00$ (Timor Tengah Selatan Regency), with the mean value of $2,860,498.1551$. This indicates that the website owned by Timor Tengah Selatan Regency is very unpopular, or with very few visitors.

The variable of on website has minimum value of 0.08 and maximum value of 1.00 , with the mean value of 0.4207 and the standard deviation of 0.31730 . This indicates that the awareness of LGs in Indonesia to disclose their financial information via website is still relatively low, or between $10.3 \%$ and $73.8 \%$.

Before testing the hypothesis, all classic assumption requirements such as normality test, autocorrelation test, multicollinearity test, and heteroscedasticity test have been done and not violated. The results of hypothesis test are shown in Table 3. 
Tabel 3

Results of Multilinear Regression Test

\begin{tabular}{|c|c|c|c|c|c|c|}
\hline & Model & $\mathrm{H}_{\mathrm{i}}$ & $\mathrm{B}$ & $\mathrm{T}$ & Sig. & Results \\
\hline \multirow[t]{11}{*}{1} & (Constant) & & -3.553 & -2.774 & .006 & \\
\hline & SIZE & + & .138 & 3.078 & 0.002 & $\mathrm{H}_{1}$ accepted \\
\hline & LEVERAGE & + & -1.512 & -.735 & 0.464 & $\mathrm{H}_{2}$ rejected \\
\hline & WEALTH & + & 0.00000037 & 3.237 & 0.001 & $\mathrm{H}_{3}$ accepted \\
\hline & AUDIT OP. & + & .014 & .622 & 0.535 & $\mathrm{H}_{4}$ rejected \\
\hline & LIQUIDITY & + & -0.000030 & -1.420 & 0.157 & $\mathrm{H}_{5}$ rejected \\
\hline & PRESS VIS. & + & -0.000000023 & -3.208 & 0.002 & $\mathrm{H}_{6}$ rejected \\
\hline & $\mathrm{R}^{2}$ & & & 0.239 & & \\
\hline & Adjusted $\mathrm{R}^{2}$ & & & 0.214 & & \\
\hline & $\mathrm{F}^{- \text {value }}$ & & & 9.440 & & \\
\hline & Asymp sig & & & 0.000 & & \\
\hline
\end{tabular}

The value of adjusted R2 (determinat coefficient) is 0.214 . It shows that $21.4 \%$ of the variable of financial information disclosure through LGs websites could be explained by the variables of size, leverage, wealth, audit opinion, liquidity, and press visibility, while the remaining $78.6 \%$ is influenced by other factors outside this research. The significance value (F test) in the regression model of this study has a smaller value $(0.000)$ than the significance level (0.05). Thus, it can be concluded that this model is feasible in predicting the disclosure of financial information through the LGs website, or the variables of size, leverage, wealth, audit opinion, liquidity, and press visibility simultaneously have an effect on financial information disclosure through LGs website.

The test result on the first hypothesis can be accepted. The result proves that the significant value of size variable is 0.002 which is less than 0.05 , and the beta coefficient has a positive direction of 0,138 . This indicates that the LGs with large total assets will strive to disclose their financial information via the LGs websites. The test result on the second hypothesis is rejected. The result proves that the significant value of leverage variable is 0.464 which is greater than 0.05 and the beta coefficient has negative direction of -1.512 . This indicates that the LGs with the great ratio of total debt to total assets do not guarantee that they will disclose their financial information via website.

The test result on the third hypothesis is accepted. The result proves that the significance value of wealth variable is 0.001 which is smaller than 0.05 , and the beta coefficient has positive direction of 0.00000037 . This indicates that the LGs, with great ratio of LGs revenue (PAD) to the total polulation, will try to disclose their financial information via LGs website. The test result on the fourth hypothesis is rejected. The result proves that the significant value of audit opinion variable is 0.535 which is greater than 0.05 and the beta coefficient 
has positive direction of 0.014 . This indicates that the LGs with less good audit opinion do not guarantee that they will not disclose their financial information via website.

The test result on the fifth hypothesis is rejected. The result proves that the significant value of liquidity variable is 0,157 which is greater than 0.05 and the beta coefficient has negative direction of -0.000030 . This indicates that the LGs with great ratio of current assets to current liabilities do not guarantee that the LGs will disclose their financial information via website.

The test result on the sixth hypothesis is rejected. The result proves that the significant value of press visibility is 0.002 which is smaller than 0.05 , and the beta coefficient has a negative direction of -0.000000023 . This indicates that the LGs with a good level of popularity of websites tend not to disclose their financial information via the website.

\section{DISCUSSION}

Of the six independent variables used, only variables of size and wealth that have positive effect on the disclosure of financial information through the Indonesian LGs website. While variables of leverage, audit opinion, liquidity, and press visibility have no effect on the disclosure of financial information through the Indonesian LGs website.

The test result of this size variable supports the researches conducted by Styles and Tennyson (2007), Garcia and Garcia (2010), Medina (2012), Trisnawati and Achmad (2014) where size has a significant effect on the disclosure of LGs financial information via website. However, the result of this study does not support the results of the researches conducted by Laswad et al (2005), Sinaga and Prabowo (2011), Rahman et al (2013), Afryansyah and Haryanto (2013). The LGs, with large size, generally have more complex problems and more inefficient resources management. This occurs because the LGs have more public service programs. Therefore, The LGs, with large size, will also have greater demands to report their assets management by disclosing information to the public so as to reduce the information asymmetry. This occurs because the LGs should bear the bonding costs such as cost and time spent to make the website as well as to reduce printing costs of reporting. So, one of the effective ways is to disclose the financial information through the website owned by the LGs.

The test result of this leverage variable does not support the results of the researches conducted by Laswad et al (2005), Rahman et al (2013), and Trisnawati and Achmad (2014) where the leverage has an effect on the disclosure of LGs financial information via website. However, the result of this study supports the results of the researches conducted by Sinaga and Prabowo (2011) and Medina (2012). Higher leverage results in the higher supervision made by the creditors since the creditors want a return on the funds lent to the local governments. The LGs that have high leverage, have greater obligation to report the loans obtained from creditors than those that have low leverage. The LGs that have high 
leverage may determine policy in disclosing their financial information only through conventional media in the form of financial statements required. While the disclosure through website may be regarded as bad news. It is too risky because anyone can access the LGs website. Therefore, the LGs avoid the disclosure of financial information via website so as not to be in the public eye by trying to cover up their financial information.

The test result of this wealth variable supports the results of the researches conducted by Laswad et al (2005), Rahman et al (2013), and Trisnawati and Achmad (2014) that the LGs wealth has an effect on the disclosure of LGs financial information via website. However, the result of this study does not support the results of the researches conducted by Sinaga and Prabowo (2011), and Afryansyah and Haryanto (2013). The LGs with high wealth shows that they can manage their finances to the maximum so that the LGs have sufficient resources to run the established programs better because they do not worry of the lack of resource allocation. However, the LGs, with high wealth, also allows the occurrence of greater abuse of resources, so the public will tend to control over the LGs performance by requiring their financial information disclosure. To bear the high cost of supervision in meeting the demands for transparency from the public, the LGs try to disclose their financial information via website because it is easier, faster, cheaper, and ccan reduce the information asymmetry.

The test result of this audit opinion variable does not support the result of the research conducted by Styles and Tennyson (2007) that the audit opinion of the LGs has an effect on the disclosure of LGs financial information via internet. However, the result of this study supports the research conducted by Trisnawati and Achmad (2014). The LGs with unqualified opinion (WTP) do not guarantee that they will disclose their financial information through website. The purpose of the opinion is to assess the fairness of the financial management reporting information. In addition, the investigation is limited to sampling and budgetary policies adopted. So far the public assumption on the LGs with unqualified opinion (WTP) is that the LGs have been running their functions well and cleanly, so that their financial management does not need to be re-examined. The heads of the LGs are usually proud of the achievement of the unqualified opinion (WTP) and thry to disseminate this information as a positive signal in financial management. But in fact it is the political policy of the LGs heads and their supporting parties so as to continue supporting the administration they run. Even though the LGs have unqualified opinion (WTP), they are still not free from some cases in financial management, among others are the Provincial Government of Riau, City Government of Palembang, and Regency Government of Bangkalan.

The test result of this liquidity variable does not support the research conducted by Simanjuntak and Widiastuti (2004) that the characteristics of companies with high liquidity ratio have relationship with the level of voluntary disclosure of the manufacturing 
companies listed in the Indonesia Stock Exchange. However, the result of this study supports the research conducted by Aly et al. (2010) in which liquidity does not prove to have an effect on the disclosure of the company's accounting information via internet in Egypt. The LGs with high liquidity give a signal that they have a large working capital with a current asset allocation which is more dominant than the current debt. With the amount of current debts which are not as big as its current assets, the LGs have a tendency to disclose the financial information held as needed only. This happens because the debt to the creditor does not become the main focus of the LGs. The LGs assume that without debt, they are still able to run the administration well.

The test result of ths press visibility variable supports the researches conducted by Garcia and Garcia (2010) and Afryansyah and Haryanto (2013) that press visibility does not prove to have an effect on the disclosure of LGs accounting information via internet. However, the result of this research does not support research conducted by Laswad, et al (2005). Empirical evidence shows that LGs prefer to be reluctant to disclose their accounting information on the website owned. The information delivered by LGs on the website could be information related to nonfinancial only or about the LGs potential and public services so as not to be in the spotlight, where it could also increase the popularity of the LGs website. The reluctance to disclose the financial information via website occurs due to the active conduct of the media that always gives negative comment on the bad performance of the elected officials. The consequence is even on the impression that the news delivered by the media is actually happening. The public will not believe in the LGs that have poor performance, in which it may decrease the confidence in the LGs performance. The existence of press visibility should bee able to motivate the LGs as a defense form so that the positive side of the LGs performance can be highlighted for the public.

\section{CONCLUSION}

Based on the analysis and discussion, it can be deduced that only variables of size and wealth that have positive effect on the disclosure of LGs financial information via website. Press visibility has negative effect indicating that the LGs are reluctant to disclose their accounting information through the website owned due to the active actions of the media that always gives negative comment on the bad performance of the LGs. LGs are more likely to disclose information related to nonfinancial or about the potential of the region and public services so as not to be in the spotlight. While the variables of leverage, audit opinion, and liquidity do not have any effect on the disclosure of LGs financial information through the website.

Limitations of this study are (1) the ability of the variables used to describe the disclosure of financial information via the website is still low, (2) periods of time in collecting the financial information from the LGs site and popular websites are not the same, (3) the data of Audit Freports of Financial Investigation Bureau (BPK) are only in 2013. 
Suggestions for further research are (1) to add other variables such as audit findings, level of education, type of area, political competition, and profitability as well as extending the measurement index in financial and non-financial. (2) to use more recent data which can provide more updates description on the financial information disclosure practices through the LGs website.

The implication of this study is that the Ministry of Home Affairs could develop a system of reward and punishment to motivate the local governments (LGs) in improving the level of financial information disclosure through the website.

\section{REFERENCES}

Alt, JE danLassen, DD 2006, 'Fiscal transparency, political parties, and debt in OECD countries',European Economic Review, vol. 50, no. 6, pp. 1403-1439.

Afryansyah, Rahmad D. dan Haryanto. 2013. Faktor-Faktor Yang Mempengaruhi Pengungkapan Informasi Akuntansi di Internet oleh Pemerintah Daerah. Diponegoro Journal of Accounting, Vol. 2, No. 3

Aly, D., J. Simon, dan K. Hussainey. 2010. Determinants Of Corporate Internet Reporting: Evidence From Egypt. Managerial Auditing Journal, Vol. 25, No. 2, pp. 182-202

Chadwick, A. 2003. Bringing E-Democracy Back In: Why It Matters For Future Research On E-Governance. Social
Science Computer Review, Vol. 21, pages 443-455

Fontanella, A. dan H. Rossieta. 2014. Pengaruh Desentralisasi Fiskal dan Kinerja Terhadap Akuntabilitas Pelaporan Keuangan Pemerintah Daerah di Indonesia. Simposium Nasional Akuntansi 17 Mataram, Lombok

Gandı'a, J. L. dan M. C. Archidona. 2008. Determinants of Website Information By Spanish City Councils. Online Information Review, Vol. 32, No. 1, pp. $35-57$

García, A. C. dan J. G. García. 2010. Determinants Of Online Reporting Of Accounting Information By Spanish Local Government Authorities. Local Government Studies, Volume 36, Issue 5.

Ghozali, I. dan A. Chariri. 2007. Teori Akuntansi. Badan Penerbit Universitas Diponegoro. Semarang

Hassan, OAG, Giorgioni, G, Romilly, P dan Power D 2009,'Thevalue-relevance of disclosure: evidence from the emerging capital market of egypt', The International Journal of Accounting, vol. 44, no. 1,pp. 79-102.

Huang, Z dan Benyoucef, M 2014,'Usability and credibility of e-government websites', Government Information Quarterly,vol. 31, pp. 584-595.

Jensen, MC, dan Meckling, WH 1976,'Theory of the firm: managerial behaviour, agency cost, and ownership structure',Journal of 
Financial Economics, vol. 3, pp. 305360.

Laswad, F, Fisher, R dan Oyelere, P 2005 , 'Determinants of voluntary internet financial reporting by local government authorities',Journal of Accounting and Public Policy,vol. 24, pp. 101-121.

Lupu, D dan Lazăr, CG 2015, 'Influence of e-government on the level of corruption in some EU',Procedia Economics and Finance, vol. 20, pp. $365-371$.

Medina, F 2012,'Faktor-faktor yang mempengaruhi transparansi informasi keuangan pada situs resmi pemerintah daerah indonesia',Skripsi, Universitas Indonesia, Jakarta.

Meón, P dan Weill, L 2005,'Does better governance foster efficiency? an aggregate frontier analysis',Economics of Governance, vol. 6, no. 1, pp. 75-90.

Moon, MJ, Lee, J, dan Roh, CY 2014, 'The evolution of internal IT applications and e-government studies in public administration: research themes and methods,Administration \& Society, vol. 46, no. 1,pp. 3-36.

Mardiasmo 2005,Akuntasi Sektor Publik, Penerbit Andi, Yogyakarta.

Martani, D, Fitriasari, D dan Annisa 2014, 'Financial and performance transparency on the local government websites in indonesia, Journal of Theoretical and Applied Information Technology, vol. 60, no.3, pp. 504-516.
Mudayastuti, S 2014,'Faktor-faktor yang mempengaruhi pengungkapan informasi oleh pemerintah daerah melalui website resmi pemerintah daerah', Skripsi, Universitas Sebelas Maret, Surakarta.

Novianty, R 2014, 'Evaluasi keterbukaan informasi keuangan daerah pada website pemerintah kota di indonesia', Skripsi, Universitas Gunadarma, Jakarta.

Oyelere, P, Laswad, F dan Fisher, R 2003,' Determinantsofinternetfinancialreporting by new zealand companies',Journal of International Financial Management \& Accounting vol. 14, no. 1, pp. 26-63.

Piotrowski, SJ dan Bertelli, A2010, 'Measuring Municipal Transparency. 14th IRSPM Conference, Bern, Switzerland.

Pattiro 2014, 'Pattiro Desak Pemerintah Daerah Publikasikan Dokumen Anggaran', diakses tanggal 6 Mei 2015, (http:// nuswantaraonline.com/2014/09/pattirodesak-pemerintah-daerah-publikasikandokumen-anggaran/).

Rahman, A, Sutaryo dan Budiatmanto, A 2013, Determinan internet financial local government reporting di indonesia. Simposium Nasional Akuntansi XVI Manado

Reddick, CG dan Turner, M 2012. Channel choice and public service delivery in canada: comparing e-government to traditional service delivery. Government Information Quarterly,vol. 29, pp. 1-11. 
Republik Indonesia. 2008. Undang-Undang Nomor 14 Tahun 2008 tentang Keterbukaan Informasi Publik

2004. Undang-

Undang Nomor 15 Tahun 2004 tentang Pemeriksaan Pengelolaan dan Tanggung Jawab Keuangan Negara . 2003. Instruksi Presiden Nomor 3 Tahun 2003 tentang Kebijakan dan Strategi Nasional Pengembangan E-Government 2012. Instruksi Menteri Dalam Negeri Nomor 188.52/1797/ SJ Tahun 2012 tentang Transparansi Pengelolaan Anggaran Daerah

Sekaran, U dan Bougie, R 2013,'Research Method for Business : a skill building approach, Wiley, Chichester.

Simanjuntak, BH dan Widiastuti, L 2004,'Faktor-faktor yang mempengaruhi kelengkapan pengungkapan laporan keuangan pada perusahaan manufaktur yang terdaftar di bursa efek jakarta' Jurnal Riset Akuntansi Indonesia, vol. 7, no.3, pp. 51-366.

Styles, AK dan Tennyson M 2007,'The accessibility of financial reporting of u.s. municipalities on the internet'Journal of Public Budgeting, Accounting \& Financial Management, vol. 19 no. 1, pp. 56-92.

Sol, DA 2013. 'The institutional, economic and social determinants of local government transparency,Journal of Economic Policy
Reform, vol. 16, no. 1, pp. 90-107.

Sinaga, YF dan Prabowo TJW2011, 'Analisis faktor-faktor yang mempengaruhi pelaporan keuangan di internet secara sukarela oleh pemerintah daerah. Jurnal Universitas Diponegoro, diunduh 9 Mei 2015.

Turley, G, Robbins, G dan McNena, S 2015, 'A framework to measure the financial performance of local governments. Local Government Studies, vol. 41, no. 3, pp. 401-420.

Trisnawati, MD dan Achmad, K 2014. Determinan publikasi laporan keuangan pemerintah daerah melalui internet. Simposium Nasional Akuntansi 17 Mataram, Lombok. 
Kurniawan Cahyo Utomo : The determinant of financial information disclosure on.....

Page 85-102 